\section{Lake Balaton: going green}

HUNGARY's Plant Protection and Agrochemical Service was originally established 25 years ago to boost agricultural production by the proper application of modern fertilizers and pesticides, a task which it carries out efficiently and well from its 20 sophisticated research centres (one in each county and one in Budapest). During the last three years, however, the centres in Zala, Veszprem and Somogy counties have taken on an additional role, the protection of the water quality of Lake Balaton. This is a task of some urgency: a recent report to the Hungarian government stated that with the present rate of chemical input, and no preventive measures, the majority of the lake will be green with eutrophication and unacceptable for leisure use within 15 years.

Lake Balaton is the largest body of fresh water in continental Europe with an area at mean water level of $595 \mathrm{~km}^{2}$, and it is Hungary's main holiday area. In 1963, a special government decree pronounced that the region should be developed primarily to meet the needs of domestic and foreign tourism. A number of highrise hotels sprang up along the lake shore - not always with sufficient attention to effluent disposal.

The main problem, however, is agriculture in the catchment basin, an area of some $5,180 \mathrm{~km}^{2}$, excluding the lake surface. The main crops are wheat, maize, rape and, on the northern shore, grapes. Modernisation of agriculture has led to a considerable increase in the use of agricultural chemicals. By 1975, the average concentration of active nitrogen phosphorus and potassium substances (NPK) had reached $400 \mathrm{~kg} / \mathrm{ha}$ in Somogy county, 330 in Veszprem, and 380 in Zala. The daily discharge into the lake via the river Zala and other feeders was $764 \mathrm{~kg}$ of total phosphorus and $1,600 \mathrm{~kg}$ of total nitrogen from plant nutrients, with an additional $254 \mathrm{~kg}$ of total phosphorus and $533 \mathrm{~kg}$ of total nitrogen from treated effluent.

To exacerbate the problem, environmental protection in Hungary was covered by a piecemeal series of laws until as recently as 1976. These were often outdated, as, for example, a 1947 order of the Ministry of the Interior which made it an offence to encourage draught animals by shouting. In 1976, however, a new and comprehensive act came into force: "On the protection of the human environment". To implement this legislation, the former Office of the Environment was upgraded and given independent status as the State Council for the Environment and Nature Conservation, with a secretary of state, $\mathrm{Dr}$ Gyorgy Gonda, at its head. To deal with the specific problem of the Balaton area, a Coordinating Council for Research on
Lake Balaton was established under the auspices of the Academy of Sciences, headed by Dr Istvan Lang, Deputy General Secretary of the Academy.

A complex ecological research programme was inaugurated, originally with some 200 subjects on the agenda. After what Dr Lang describes as "repeated professional consultations" these were finally whittled down to three priority research areas: factors characterising, impairing or improving water quality in the lake; the social sciences background to environmental decisions in the region; and the environmental factors affecting recreation and tourism. In addition, two longer-term studies were also given priority status: the review and synthesis of the principal scientific results and professional experience relating to the region, and the working out of the scientific basis for an integrated monitoring system.

Some 40 research institutes, university departments and industrial research laboratories were drawn into the project. Government guidelines indicated that the lake water from now on must be used for drinking and recreation only; even treated effluent is to be excluded. While civil engineers and architects are busy on a crash programme of sewerage development, the three plant protection stations in the counties bordering the lake have joined forces with the National Water Authority to monitor and prevent the run-off of chemicals.

Close to the lake and its tributaries, an upper limit of $160 \mathrm{~kg} / \mathrm{h}$ a of active NPK has been set, with some pesticides and fertilizers forbidden completely. The restricted zone is normally $1 \mathrm{~km}$ wide, measured from the bank, with very severe restrictions south of highway 71 on the north shore of the lake. Although a reduction in fertilizer use should lead to decreased crop yield, recent rises in the price of fertilizers have raised the general question of how cost-effective it is to apply massive doses of fertilizer. Many of the erst while lavish cooperatives are in any case settling for slightly lower yields. One of the main research subjects for the Plant Protection and Agrochemical Service is how to increase crop-yield without increasing the amount of fertilizer used. As far as pesticides are concerned, the Plant Protection and Agrochemical Service was already operating a compulsory soil and residue monitoring service for food crops. In the three lake counties, this was extended, in 1976, to the monitoring of pesticide run-offs. After an initial survey carried out together with the National Water Authority, a set of soil and water sampling sites were chosen at random positions. These sites are monitored every fortnight or month (according to agricultural conditions). According to Dr Sandor Bordas of the

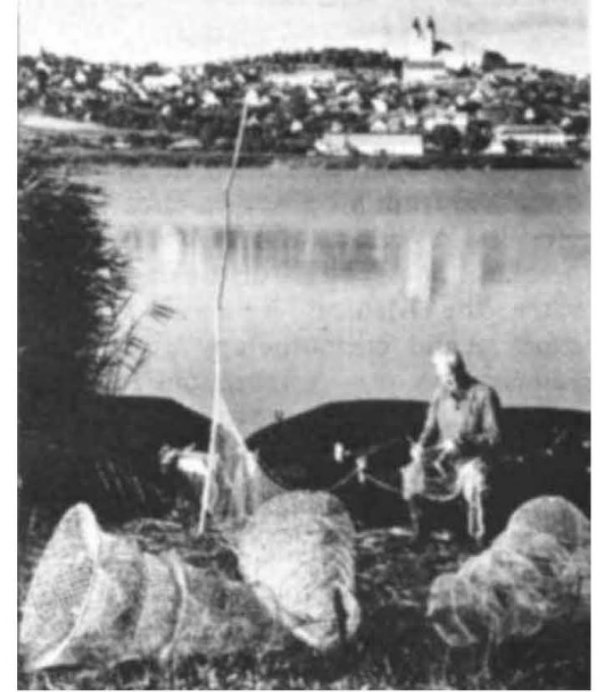

Balaton fisherman mends his nets

Budapest Plant Protection and Agrochemical Station, it is now possible, on the basis of the last three years' results "to follow the dynamics of pollution, and to have a regular view of the quality of water and soil in relation to pesticides".

According to the research team at the Zalaegerszeg Plant Protection and Agrochemical Station, the new restrictions will have little overall effect on the region's agriculture. With some crops, however, there may be "difficulties". Vine-growing, in particular, is now very difficult in the restricted zone of the north shore, and the biological research institute at Szeged has started research into disease-resistant strains, which would reduce the need for pesticides. So far, however, no variety has been obtained that is entirely resistant to Plasmopora viticola (downy mildew). Should vinegrowers wish to restock, they explained, the government will give direct financial assistance to state or cooperative vineyards. Much of Hungary's viticulture, however, takes place in the private sector, on the small 'household plots' which provide some $30 \%$ of all Hungary's crops. Small growers wishing to make the changeover, said the Zalaegerszeg team, get 8 years free of tax on the new vineyard.

The small grower, incidentally, is potentially one of the weak links in the whole plant protection service. On cooperative and state farms, the use of agricultural chemicals is strictly controlled by specially trained Plant Protection Engineers. No such restrictions can be imposed on the private grower - other than by limiting the sale of the most sophisticated products to the state sector. Theoretically, then, there is nothing to stop the owners of summer cottages on the north shore from pouring unacceptable concentrations of fertilizer on to their gardens - except a growing public awareness with ecological problems, which is currently being promoted by a massive campaign in the media.

Vera Rich 